\title{
Stosunek przedstawicieli pokolenia Y do inicjatyw z zakresu zielonego zarządzania zasobami ludzkimi
}

\author{
WERONIKA MusZYŃSKA
}

\author{
Szkoła Doktorska Szkoły Głównej Handlowej w Warszawie
}

\begin{abstract}
Pomimo że koncepcja zielonego zarządzania zasobami ludzkimi jest szeroko rozpoznana $\mathrm{w}$ literaturze, to niewiele jest polskich publikacji, w których uwzględniono stosunek przedstawicieli pokolenia Y (ur. w latach 80. i 90. XX w.) do inicjatyw z tego zakresu. Celem artykułu jest zbadanie, jak członkowie pokolenia Y postrzegają inicjatywy z zakresu zielonego zarządzania zasobami ludzkimi oraz wskazanie, czy wykształcenie warunkuje ich nastawienie do green HRM. Praca ma charakter teoretyczno-empiryczny. Posłużono się metodą studiów literatury przedmiotu oraz badaniami ilościowymi. Zdaniem badanych najskuteczniejszą inicjatywą z zakresu green HRM jest organizacja szkoleń uświadamiających i rozwijających umiejętności ekologiczne. Natomiast wykształcenie w ograniczonym zakresie warunkuje stosunek członków pokolenia Y do inicjatyw green HRM. Badanie przeprowadzono na niereprezentatywnej grupie badawczej, co implikuje ograniczenia.
\end{abstract}

Słowa kluczowe: zielone zarządzanie zasobami ludzkimi, pokolenie Y, wykształcenie Kody klasyfikacji JEL: J29, M12, M54 


\section{W prowadzenie}

W obszarze ZZL wciąż pojawiają się nowe koncepcje, które pozwalają spojrzeć $\mathrm{z}$ innej perspektywy na sposób zarządzania zasobami ludzkimi. Jedną z nich jest zielone zarządzanie zasobami ludzkimi (Green Human Resources Management - green HRM) (Zaleśna, Wyrzykowska, 2017). W literaturze wskazuje się, że stanowi ono odpowiedź na nasilające się problemy społeczne i ekologiczne we współczesnym świecie (Różańska-Bińczyk i in., 2020). Dokonując przeglądu literatury, należy stwierdzić, że pomimo iż jest to koncepcja stosunkowo młoda, to jednak w ostatnich latach obserwuje się znaczący wzrost jej popularności (Ehnert, 2009; Bombiak, Marciniuk-Kluska, 2018; Geetha, Sammanasu, 2020). Zielone zarządzanie zasobami ludzkimi jako koncepcja jest dopiero rozpoznawane (Bugdol, Stańczyk, 2021) w polskiej literaturze, ale już w tej chwili przypisuje się mu wiele możliwości rozwoju zarówno w aspekcie teoretycznym nauk o zarządzaniu, jak i w samej praktyce zarządzania.

Również obecna sytuacja związana z pandemią COVID-19 wskazuje, że działalność firm w obszarze zielonego zarządzania zasobami ludzkimi w perspektywie kolejnych kilku lat z postulatu stanie się bezwzględną potrzebą. Zarówno Rada Unii Europejskiej, jak i praktycy biznesu podkreślają, że sytuacja, z którą obecnie mierzą się pracodawcy, w perspektywie długoterminowej przyniesie korzyści przede wszystkim organizacjom, które rozwijają się w nurcie green HRM (Różańska-Bińczyk, 2020).

W szczególności w zakresie zarządzania zasobami ludzkimi niezbędne jest rozpoznanie znaczenia zielonych inicjatyw, ale przede wszystkim podejmowanie działań przyjaznych środowisku poprzez wprowadzanie zmian w istniejących procesach i praktykach (Mishra i in., 2014). Zielone zarządzanie powinno być globalnym priorytetem dla dzisiejszych, myślących przyszłościowo organizacji (Jackson i in., 2011; 2014). Przejście w kierunku zielonych praktyk w każdej organizacji wymaga jednak wsparcia działów HR (Yong, Mohd-Yusoff, 2016). Kluczowa rola specjalistów HR w odniesieniu do zielonych inicjatyw jest podkreślana w wielu badaniach (m.in. Jabbour, Santos, 2008; Jabbour, 2011).

„Bycie zielonym” interesuje przedstawicieli najmłodszych pokoleń na rynku pracy (Jain, D’lima, 2018). To od nich w największym stopniu zależeć będzie, czy w najbliższej przyszłości w organizacjach z powodzeniem realizowane będą inicjatywy z zakresu zielonego zarządzania zasobami ludzkimi. Jednak już teraz organizacje, które pragną łączyć praktyki z zakresu zarządzania środowiskowego i zarządzania zasobami ludzkimi oraz angażować w nie przedstawicieli pokolenia $\mathrm{Y}$ (tzw. milenialsów, ur. w latach 80. i 90. XX w.), powinny umiejscowić ideę zrównoważonego rozwoju w centrum procesów kadrowych organizacji, a także znaleźć sposoby, aby 
nieustannie rozwijać „zielone” umiejętności pracowników i motywować ich do proekologicznej aktywności (Różańska-Bińczyk, 2020).

Pomimo że tematyka zielonego zarządzania zasobami ludzkimi jest dobrze rozpoznana - zwłaszcza w międzynarodowej literaturze (Shah, 2019), to wciąż istnieją obszary, które nie zostały jeszcze w wystarczającym stopniu zbadane (Ren i in., 2018). Są to m.in. inicjatywy z zakresu zielonego zarządzania zasobami ludzkimi, które w opinii przedstawicieli pokolenia Y są skuteczne, a co się z tym łączy, w które sami chcieliby się włączać. Podjęcie badań w powyższym obszarze pozwoli uzupełnić niewielką liczbę polskich publikacji, w których odniesiono się do inicjatyw z zakresu zielonego zarządzania zasobami ludzkimi z perspektywy członków pokolenia Y. Celem szczegółowym artykułu jest natomiast wskazanie, czy wykształcenie przedstawicieli pokolenia $Y$ warunkuje ich stosunek do inicjatyw z zakresu zielonego zarządzania zasobami ludzkimi.

Na podstawie literaturowych źródeł wtórnych przyjęto następujące hipotezy badawcze:

Hipoteza 1: Im wyższe wykształcenie posiadaja przedstawiciele pokolenia Y, tym wyrażaja bardziej pozytywny stosunek do inicjatyw z zakresu zielonego zarządzania zasobami ludzkimi.

Hipoteza 2: Przedstawiciele pokolenia Y chcieliby włączać się tylko $w$ te inicjatywy z zakresu zielonego zarządzania zasobami ludzkimi, które sami uznaja za najbardziej skuteczne działania w tym zakresie.

Do weryfikacji przyjętych hipotez posłużono się badaniami ilościowymi z zastosowaniem kwestionariusza ankiety (CAWI).

Artykuł zawiera oprócz wprowadzenia część teoretyczną (dwa rozdziały) i empiryczną oraz zakończenie. Dla realizacji celu pracy posłużono się metodą studiów literatury przedmiotu i innych źródeł wtórnych, a następnie przeprowadzono badania ilościowe w celu przetestowania hipotez i sformułowania wniosków.

\section{Istota zielonego zarządzania zasobami ludzkimi}

Koncepcja zielonego zarządzania zasobami ludzkimi ewoluuje wraz z rozwojem literatury dotyczącej zrównoważonego rozwoju (Bunge i in., 1996; Marcus, Fremeth, 2009). Uważa się, że bodźcem do jej ewolucji jest rosnąca potrzeba zintegrowania koncepcji zrównoważonego rozwoju z działaniami wewnątrz organizacji i podejmowaniem decyzji (Howard-Grenville i in., 2014; Marcus, Fremeth, 2009). W literaturze przyjmuje się, że zielone zarządzanie zasobami ludzkimi stanowi komponent koncepcji zrównoważonego zarządzania zasobami ludzkimi odnoszący się do kwestii ekologicznych jako fundamentu podejmowania decyzji kadrowych. Różańska-Bińczyk 
i in. (2020) podkreślają, że green HRM uznaje się za istotny element udanego wdrożenia koncepcji zrównoważonego rozwoju w przedsiębiorstwie, w którym zarówno cele ekonomiczne, społeczne, jak i ekologiczne powinny być włączane do każdego z procesów zarząadzania zasobami ludzkimi. Mowa tutaj m.in. o dokonywaniu opisów stanowisk pracy, prowadzeniu rekrutacji i selekcji, szkoleniu, ocenianiu czy nagradzaniu (Jabbour, 2011; Renwick i in., 2013). Różańska-Bińczyk i in. (2020) wskazują, że zielone inicjatywy powinny być realizowane również na etapie zwalniania pracowników.

Odwołując się do literatury, koncepcja zielonego zarządzania zasobami ludzkimi jest definiowana jako „systematyczne, planowane dostosowania typowych praktyk ZZL do celów środowiskowych organizacji" (Jabbour, 2011). Z kolei K.F. Ackermann (2017) stwierdza, że „są to praktyki zarządzania zasobami ludzkimi opracowane i wdrożone w celu promowania wśród pracowników zachowań zwiększających efektywność ekologiczną całej firmy". Zielone zarządzanie zasobami ludzkimi postrzega się również jako zaplanowaną i ciągłą zmianę w organizacji (Yong i in., 2019).

Głównym celem zielonego zarządzania zasobami ludzkimi jest budowanie i rozwijanie wrażliwości ekologicznej pracowników, tworzenie proekologicznego środowiska pracy i kreowanie ekologicznie odpowiedzialnych postaw pracowników, które następnie - jako model funkcjonowania - znajdą zastosowanie w sferze prywatnej (Bombiak, 2019). Jak stwierdzają Ren i in. (2018), do osiągnięcia celów zielonego zarządzania zasobami ludzkimi wymagane jest nie tylko przestrzeganie formalnych zasad, ale także zaangażowanie pracowników i akceptacja dobrowolnych inicjatyw. To właśnie od pracowników, a konkretnie ich umiejętności, wiedzy oraz świadomości ekologicznej, zależy również sukces przedsiębiorstwa w procesie projektowania i realizowania inicjatyw zrównoważonego rozwoju (Różańska-Bińczyk i in., 2020). Ponadto, jak stwierdza Jain (2009), wdrożenie zielonych inicjatyw pomaga organizacjom znaleźć różne sposoby na obniżenie kosztów bez utraty ich największych talentów.

Sięgając do literatury, Różańska-Bińczyk i in. (2020) dokonali podziału praktyk z zakresu zielonego zarządzania zasobami ludzkimi na następujące kategorie:

1) zielone planowanie zasobów ludzkich, czyli branie pod uwagę zadań związanych z ochroną środowiska podczas sporządzania opisów stanowisk pracy czy uregulowanie postaw i zachowań proekologicznych w kodeksach postępowania etycznego,

2) zielone pozyskiwanie pracowników zakładające, że zielone kompetencje pracowników są elementem obligatoryjnym profilu wymagań na każdym stanowisku pracy; w organizacji dąży się do zatrudniania osób charakteryzujących się rozwiniętą świadomością ekologiczną,

3) zielony rozwój pracowników, który jest realizowany m.in. podczas szkoleń uświadamiających i rozwijających umiejętności ekologiczne pracowników, 
4) zielone motywowanie pracowników rozumiane jako zapewnienie im możliwości wykorzystania zdobytej wiedzy i umiejętności w celu poprawienia efektywności ekologicznej całej organizacji,

5) zielone zarządzanie wydajnością pracowników oznaczające m.in. włączanie kryteriów ekologicznych do ich oceny okresowej. Dzięki temu pracownicy wiedzą, jaki jest ich wkład w osiąganie efektywności ekologicznej całej organizacji, i być może zmotywuje ich to do promowania oraz udziału w inicjatywach z zakresu ochrony środowiska.

Dzięki wdrożeniu praktyk z zakresu zielonego zarządzania zasobami ludzkimi sam pracodawca może osiągnąć wiele korzyści. Zdaniem Różańskiej-Bińczyk (2020) wśród nich należy wskazać przede wszystkim na:

1) pozyskanie i utrzymanie lojalnych pracowników, którzy identyfikują się z misją organizacji oraz pragną realizować jej cele,

2) ukształtowanie pozytywnego wizerunku pracodawcy zarówno wewnątrz organizacji, jak i w otoczeniu zewnętrznym,

3) podniesienie poziomu konkurencyjności przedsiębiorstwa - green HRM może stanowić sposób na skuteczne budowanie przewagi konkurencyjnej na rynku,

4) współtworzenie świadomego społeczeństwa wrażliwego na kwestie ochrony środowiska.

W dotychczasowych badaniach odnoszących się do koncepcji zielonego zarządzania zasobami ludzkimi przyjmowano głównie perspektywę behawioralną (Dubois C.L.Z., Dubois D.A., 2012). W badaniach tych dominują dwa poziomy analizy: poziom pracownika (indywidualnego) i poziom organizacji. Niektóre z nich uwzględniają również zjawiska na poziomie grupy. Zdaniem Ren i in. (2018) pełne zrozumienie idei zielonego zarządzania zasobami ludzkimi będzie prawdopodobnie wymagało wielopoziomowego podejścia. W badaniu empirycznym przeprowadzonym dla realizacji celów artykułu zastosowano analizę na poziomie indywidualnego pracownika. W wielu badaniach (Harvey i in., 2013; Paillé i in., 2014), wykazano, że polityka i praktyki zarządzania zasobami ludzkimi są powiązane z proekologicznymi zachowaniami pracowników na poziomie indywidualnym.

\section{Charakterystyka pokolenia Y}

Jak zauważa B. Fatyga (1999), „pokolenie” czy „wspólnota pokoleniowa” to grupa osób, które ze względu na wspólne okoliczności dorastania łączą te same cechy. Na potrzeby pracy przyjęto, że pokolenie Y tworzą osoby urodzone w latach 1984-1998, i to właśnie tę grupę poddano dalszej charakterystyce z uwzględnieniem oczekiwań i potrzeb formułowanych przez jej członków na rynku pracy. Należy jednak 
uwzględnić fakt, że, zdaniem B. Sajduka (2015), pojęcie pokolenia Y jest obarczone arbitralnością i opiera się na nienaturalnym przyporządkowaniu ludzi do pewnej grupy. Stwierdza on, że pokolenie Y to przede wszystkim kategoria publicystyczna.

Analizując grupę, jaką stanowią przedstawiciele pokolenia Y, można wskazać, że są to przede wszystkim osoby dobrze wykształcone i tolerancyjne, które cechuje pewność siebie i przekonanie o własnej wyjątkowości. W efekcie rodzi to ich silną awersję wobec krytyki (Bajdak i in., 2018). W odniesieniu do rynku pracy członkom tego pokolenia należy przypisać przede wszystkim ambicję, kreatywność i innowacyjność. W przeciwieństwie do wcześniejszych pokoleń ponad sukces zawodowy stawiają oni życie prywatne i realizację swoich pasji. W związku z tym, że przedstawicieli pokolenia Y charakteryzuje silne poczucie własnej wartości, są oni raczej niechętni do nadmiernego poświęcania się pracy oraz nie przywiązują się do konkretnej firmy. Ponadto członkowie pokolenia Y twierdzą, że znajomość języków obcych i ukończone studia uprawniają ich do stawiania wymagań wobec pracodawców (Muszyńska, 2020).

Przedstawiciele pokolenia Y oczekują od pracodawców zagwarantowania im odpowiednich warunków płacowych czy ponoszenia inwestycji w ich dalszy rozwój zawodowy (Baran, Kłos, 2014). Wśród sygnalizowanych przez nich potrzeb należy wymienić m.in. nieustanne otrzymywanie informacji zwrotnych (Kusluvan S., Kusluvan Z., 2000), otwarte omawianie zgłaszanych pomysłów, możliwość aktywnego udziału w spotkaniach zespołowych czy odbywania konsultacji z bezpośrednim przełożonym (Lebowitz, 2016). Młodzi ludzie pragną zdobywać nowe doświadczenia i umiejętności nie tylko w życiu prywatnym, ale również zawodowym. Przedstawiciele pokolenia $Y$ często zgłaszają potrzebę udziału w programach mentoringowych oraz zarówno wewnętrznych, jak i zewnętrznych szkoleniach.

Należy również zauważyć, że członkowie pokolenia Y szczególnie doceniają przyjazną atmosferę w miejscu pracy, która sprzyja wymianie pomysłów i tworzeniu innowacyjnych rozwiązań, elastyczny czas pracy (Muszyńska, 2020) oraz przejrzyste ścieżki rozwoju zawodowego. Istotne jest również to, że poszukują oni nowego zestawu nagród w zamian za ich wysiłek podejmowany w pracy, do którego należą elastyczne warunki pracy i możliwości zaangażowania się w działania społecznie odpowiedzialne, takie jak inicjatywy ekologiczne (Solnet i in., 2012).

Jak wspomniano, aby osiągnąć cele zielonego zarządzania zasobami ludzkimi (czy szerzej: zrównoważonego rozwoju), organizacje powinny stosować odpowiednie praktyki oraz stymulować swoich pracowników (Bangwal, Tiwari, 2015), do czego odniesiono się w prowadzonym badaniu. 


\section{Badanie własne}

\section{Metodyka przeprowadzonego badania}

Mając na względzie realizację celu pracy i weryfikację hipotez badawczych, przeprowadzono badania ilościowe $z$ wykorzystaniem internetowego kwestionariusza ankiety (CAWI). Za taką formą badania przemawiało duże zróżnicowanie przestrzenne respondentów (obszar całej Polski), powszechny dostęp do Internetu, a także względy sanitarno-epidemiczne. Badanie zrealizowano w listopadzie $2020 \mathrm{r}$.

Próbę badawczą stanowili przedstawiciele pokolenia Y zamieszkujący obszar całej Polski ( $\mathrm{N}=126)$ (przy założeniu, że grupę tę tworzą osoby urodzone w latach 1984-1998). Dobór próby badawczej był przypadkowy i nielosowy, natomiast wyniki badania nie są reprezentatywne.

Przed przystąpieniem do właściwego badania przeprowadzono badania pilotażowe, którymi objęto sześć osób. Do finalnej analizy wykorzystano 121 kwestionariuszy ankiety (96\%). Pięć ankiet (4\%) wypełniły osoby urodzone przed $1984 \mathrm{r}$. lub po 1998 r., dlatego ich wyników nie uwzględniono w dalszej analizie. W celu potwierdzenia wieku ankietowanych w metryczce zamieszczono dodatkowe pytanie kontrolne tak, aby mogli oni samodzielnie wpisać swoją datę urodzin.

Kobiety stanowiły $69,2 \%$ badanej próby $(\mathrm{N}=84)$, natomiast mężczyźni 30,8\% ( $\mathrm{N}=37)$. Najliczniejszą grupę badanych $(\mathrm{N}=78 ; 64,5 \%)$ tworzyły osoby deklarujące wykształcenie wyższe niepełne, na potrzeby badania rozumiane jako obecne kształcenie się na studiach licencjackich lub magisterskich, natomiast najmniej liczną grupę reprezentowały osoby o wykształceniu podstawowym $(\mathrm{N}=3 ; 2,5 \%)$.

Na potrzeby badania empirycznego przyjęto, że jedną ze zmiennych różnicującą stosunek przedstawicieli pokolenia $Y$ do inicjatyw z zakresu zielonego zarządzania zasobami ludzkimi jest wykształcenie. W literaturze wskazuje się, że są to osoby wykształcone i odczuwające potrzebę pogłębiania swojej wiedzy (Striker, 2011; Mazur-Wierzbicka, 2015). Odnosząc się do pokolenia Y na rynku pracy, należy stwierdzić, że jego przedstawiciele stanowią grupę trudną w zarządzaniu (Kmiotek, 2012), ale jednocześnie bardzo zainteresowaną indywidualnym rozwojem i zdobywaniem nowych doświadczeń zawodowych.

Na potrzeby badania ilościowego przyjęto, że im wyższe wykształcenie posiadają przedstawiciele pokolenia Y, tym wyrażają bardziej pozytywny stosunek do inicjatyw z zakresu zielonego zarządzania zasobami ludzkimi. Rozkład wykształcenia w próbie badawczej zaprezentowano w tabeli 1 . 
Tabela 1. Rozkład wykształcenia w próbie badawczej

\begin{tabular}{|l|r|r|}
\hline \multicolumn{1}{|c|}{ Wykształcenie } & Liczba & $\%$ \\
\hline Podstawowe & 3 & 2,5 \\
\hline Zawodowe & 4 & 3,3 \\
\hline Średnie & 14 & 11,5 \\
\hline Wyższe niepełne (w trakcie studiów licencjackich/magisterskich) & 78 & 64,5 \\
\hline Wyższe (tytuł magistra) & 18 & 14,9 \\
\hline Wyższe (tytuł doktora lub wyższy) & 4 & 3,3 \\
\hline Ogółem & 121 & 100,0 \\
\hline
\end{tabular}

Źródło: opracowanie własne na podstawie badania własnego.

Ponadto w kwestionariuszu ankiety wykorzystano zmienne opisujące stosunek przedstawicieli pokolenia $Y$ do inicjatyw z zakresu zielonego zarządzania zasobami ludzkimi (tabela 2).

Tabela 2. Zmienne opisujące stosunek przedstawicieli pokolenia Y do inicjatyw z zakresu zielonego zarządzania zasobami ludzkimi

\begin{tabular}{|c|c|c|c|}
\hline Zmienne wskazane w badaniu & $\begin{array}{l}\text { Opis zmiennych wskazanych } \\
\text { w badaniu }\end{array}$ & $\begin{array}{c}\text { Pytania } \\
\text { w kwestio- } \\
\text { nariuszu } \\
\text { ankiety }\end{array}$ & Forma pomiaru \\
\hline $\begin{array}{l}\text { Zielone planowanie zasobów } \\
\text { ludzkich: wprowadzenie } \\
\text { kodeksu postępowania } \\
\text { etycznego uwzględniającego } \\
\text { postawy i zachowania } \\
\text { proekologiczne }\end{array}$ & $\begin{array}{l}\text { Stosunek respondentów } \\
\text { do wprowadzenia przez } \\
\text { pracodawcę kodeksu } \\
\text { postępowania etycznego } \\
\text { uwzględniającego postawy } \\
\text { i zachowania proekologiczne } \\
\text { w celu wdrażania green HRM }\end{array}$ & 1.1 . & \multirow{3}{*}{$\begin{array}{l}\text { Skala 5-stopniowa } \\
\text { (od „absolutnie } \\
\text { się nie zgadzam” } \\
\text { do „absolutnie się } \\
\text { zgadzam”) i skala } \\
\text { 5-stopniowa } \\
\text { (od „absolutnie } \\
\text { tak” do } \\
\text { „absolutnie nie”) }\end{array}$} \\
\hline $\begin{array}{l}\text { Zielone pozyskiwanie } \\
\text { pracowników: preferowanie } \\
\text { kandydatów charakteryzujących } \\
\text { się rozwiniętą świadomością } \\
\text { ekologiczną i posiadających } \\
\text { np. doświadczenie w realizacji } \\
\text { ekologicznych projektów }\end{array}$ & $\begin{array}{l}\text { Stosunek respondentów do } \\
\text { preferowania przez pracodawcę } \\
\text { kandydatów charakteryzujących } \\
\text { się rozwiniętą świadomością } \\
\text { ekologiczną i posiadających } \\
\text { np. doświadczenie w realizacji } \\
\text { ekologicznych projektów }\end{array}$ & 1.2. & \\
\hline $\begin{array}{l}\text { Zielony rozwój pracowników: } \\
\text { organizacja szkoleń } \\
\text { uświadamiających } \\
\text { i rozwijających umiejętności } \\
\text { ekologiczne pracowników } \\
\text { każdego szczebla }\end{array}$ & $\begin{array}{l}\text { Stosunek respondentów } \\
\text { do organizacji szkoleń } \\
\text { uświadamiających } \\
\text { i rozwijających umiejętności } \\
\text { ekologiczne pracowników } \\
\text { każdego szczebla w ramach } \\
\text { działań z zakresu green HRM }\end{array}$ & 1.3. & \\
\hline
\end{tabular}




\begin{tabular}{|l|l|c|l|}
\hline Zmienne wskazane w badaniu & $\begin{array}{c}\text { Opis zmiennych wskazanych } \\
\text { w badaniu }\end{array}$ & $\begin{array}{c}\text { Pytania } \\
\text { w kwestio- } \\
\text { nariuszu } \\
\text { ankiety }\end{array}$ & Forma pomiaru \\
\hline $\begin{array}{l}\text { Zielone motywowanie } \\
\text { pracowników: publiczne } \\
\text { pochwały/wyróżnienia } \\
\text { i przyznawanie certyfikatów za } \\
\text { działalność proekologiczną }\end{array}$ & $\begin{array}{l}\text { Stosunek respondentów } \\
\text { do udzielania publicznych } \\
\text { pochwał/wyróżnień } \\
\text { i przyznawania certyfikatów } \\
\text { za działalność proekologiczną } \\
\text { przez pracodawcę }\end{array}$ & 1.4. & $\begin{array}{l}\text { Skala 5-stopniowa } \\
\text { (od „absolutnie } \\
\text { się nie zgadzam” } \\
\text { do „absolutnie się } \\
\text { zgadzam”) i skala }\end{array}$ \\
\hline $\begin{array}{l}\text { Zielone zarządzanie } \\
\text { wydajnością pracowników: } \\
\text { informowanie o wkładzie } \\
\text { w osiągnięcia firmy w obszarze } \\
\text { efektywności ekologicznej }\end{array}$ & $\begin{array}{l}\text { Stosunek respondentów do } \\
\text { informowania ich o wkładzie } \\
\text { w osiągnięcia firmy w obszarze } \\
\text { efektywności ekologicznej }\end{array}$ & 1.5. & $\begin{array}{l}\text { 5-stopniowa } \\
\text { (od „absolutnie } \\
\text { tak” do } \\
\text {,absolutnie nie”) }\end{array}$ \\
\hline
\end{tabular}

Źródło: opracowanie własne na podstawie Różańska-Bińczyk, M. Matejun, Matusiak. (b.d.). Praktyki green HR we wspótczesnych przedsiębiorstwach.http://slz.sgh.waw.pl/wp-content/uploads/2020/11/012_I_05.pdf, 2.01.2021.

\section{Wyniki przeprowadzonego badania}

Do celów badawczych należało określenie związku między wykształceniem przedstawicieli pokolenia Y a ich stosunkiem do inicjatyw z zakresu zielonego zarządzania zasobami ludzkimi podejmowanych przez pracodawcę. W tym celu wykorzystano współczynnik korelacji Pearsona ${ }^{1}$.

Umiarkowana korelacja dodatnia wystąpiła między zmienną opisaną jako wykształcenie a pytaniem 1.1., w którym badano stosunek przedstawicieli pokolenia Y do wprowadzenia przez pracodawcę kodeksu postępowania etycznego uwzględniającego postawy i zachowania proekologiczne oraz pytaniem 1.3., w którym monitorowano stosunek do organizacji szkoleń uświadamiających i rozwijających umiejętności ekologiczne pracowników każdego szczebla (odpowiednio rp =0,51 i rp =0,43). W tym zakresie wskazano na istotność zależności między zmiennymi opisanymi jako wykształcenie i stosunek do inicjatywy z zakresu zielonego zarządzania zasobami ludzkimi. W odniesieniu do pytań 1.2., 1.4., 1.5. obserwuje się korelację słabą, wskazującą na brak związku pomiędzy wybranymi zmiennymi.

1 Interpretacja wielkości współczynnika korelacji Pearsona:

poniżej 0,2 - korelacja słaba (praktycznie brak związku),

0,2-0,4 - korelacja niska (zależność wyraźna),

0,4-0,6 - korelacja umiarkowana (zależność istotna),

0,6-0,8 - korelacja wysoka (zależność znaczna),

0,8-0,9 - korelacja bardzo wysoka (zależność bardzo duża),

0,9-1,0 - zależność praktycznie pełna. 
Do celów badawczych należało również ustalenie, jakie inicjatywy z zakresu zielonego zarządzania zasobami ludzkimi przedstawiciele pokolenia Y uznają za najskuteczniejsze oraz takie, w które sami chcieliby się włączyć.

Jak wynika $z$ analizy rezultatów badania, zdaniem $54,2 \%$ respondentów najskuteczniejszym sposobem zielonego zarządzania zasobami ludzkimi jest organizacja szkoleń uświadamiających i rozwijających umiejętności ekologiczne pracowników każdego szczebla. Na drugim miejscu znalazło się wprowadzenie przez pracodawcę kodeksu postępowania etycznego uwzględniającego postawy i zachowania proekologiczne (34,5\% odpowiedzi), natomiast na trzecim informowanie o wkładzie w osiągnięcia firmy w obszarze efektywności ekologicznej (tak odpowiedziało $24 \%$ respondentów).

Przedstawiciele pokolenia Y nie tylko wskazują wiele inicjatyw, których podjęcie, ich zdaniem, może pomóc pracodawcy wdrażać zasady green HRM, ale również sami chętnie włączaliby się w takie działania. Najwięcej, bo aż 76,7\%, respondentów wyraża chęć udziału w szkoleniach uświadamiających i rozwijających umiejętności ekologiczne. $Z$ kolei najmniej liczna grupa przedstawicieli pokolenia $Y(t j .13,6 \%)$ jest zainteresowana promowaniem i udziałem w inicjatywach z zakresu ochrony środowiska.

Aby zbadać związki zachodzące pomiędzy wybranymi zmiennymi, ponownie wykorzystano współczynnik korelacji Pearsona (tabela 3).

Tabela 3. Korelacje między wybranymi inicjatywami z zakresu zielonego zarządzania zasobami ludzkimi a chęcią włączenia się w nie wyrażaną przez przedstawicieli pokolenia $\mathrm{Y}$

\begin{tabular}{|c|c|c|c|c|}
\hline $\begin{array}{c}\text { Pytania } \\
\text { w kwestio- } \\
\text { nariuszu } \\
\text { ankiety }\end{array}$ & $\begin{array}{c}\text { Zmienne wskazane } \\
\text { w badaniu }\end{array}$ & $\begin{array}{c}\text { Pytania } \\
\text { w kwestio- } \\
\text { nariuszu } \\
\text { ankiety }\end{array}$ & $\begin{array}{c}\text { Zmienne wskazane } \\
\text { w badaniu }\end{array}$ & $\begin{array}{c}\text { Wartość } \\
\text { wskaźnika } \\
\text { korelacji Pearsona } \\
\text { dla uśrednionych } \\
\text { wartości }\end{array}$ \\
\hline 1.1. & $\begin{array}{l}\text { Zielone planowanie zasobów } \\
\text { ludzkich: wprowadzenie } \\
\text { kodeksu postępowania } \\
\text { etycznego uwzględniającego } \\
\text { postawy i zachowania } \\
\text { proekologiczne }\end{array}$ & 3.1. & $\begin{array}{l}\text { Udział w tworzeniu } \\
\text { kodeksu postępowania } \\
\text { etycznego } \\
\text { uwzględniającego } \\
\text { postawy i zachowania } \\
\text { proekologiczne }\end{array}$ & 0,61 \\
\hline 1.3. & $\begin{array}{l}\text { Zielony rozwój } \\
\text { pracowników: organizacja } \\
\text { szkoleń uświadamiających } \\
\text { i rozwijających umiejętności } \\
\text { ekologiczne pracowników } \\
\text { każdego szczebla }\end{array}$ & 3.2. & $\begin{array}{l}\text { Udział w szkoleniach } \\
\text { uświadamiających } \\
\text { i rozwijających } \\
\text { umiejętności } \\
\text { ekologiczne } \\
\text { pracowników każdego } \\
\text { szczebla }\end{array}$ & 0,68 \\
\hline
\end{tabular}




\begin{tabular}{|c|c|c|c|c|}
\hline $\begin{array}{c}\text { Pytania } \\
\text { w kwestio- } \\
\text { nariuszu } \\
\text { ankiety }\end{array}$ & $\begin{array}{c}\text { Zmienne wskazane } \\
\text { w badaniu }\end{array}$ & $\begin{array}{c}\text { Pytania } \\
\text { w kwestio- } \\
\text { nariuszu } \\
\text { ankiety }\end{array}$ & $\begin{array}{c}\text { Zmienne wskazane } \\
\text { w badaniu }\end{array}$ & $\begin{array}{c}\text { Wartość } \\
\text { wskaźnika } \\
\text { korelacji Pearsona } \\
\text { dla uśrednionych } \\
\text { wartości }\end{array}$ \\
\hline 1.5. & $\begin{array}{l}\text { Zielone zarządzanie } \\
\text { wydajnością pracowników: } \\
\text { informowanie o wkładzie } \\
\text { w osiągnięcia firmy } \\
\text { w obszarze efektywności } \\
\text { ekologicznej }\end{array}$ & 3.3. & $\begin{array}{l}\text { Promowanie i udział } \\
\text { w inicjatywach } \\
\text { z zakresu ochrony } \\
\text { środowiska }\end{array}$ & 0,18 \\
\hline
\end{tabular}

Źródło: opracowanie własne na podstawie badania własnego.

W wyniku przeprowadzonej analizy można stwierdzić, że między pytaniami 1.3. i 3.2., odnoszącymi się do szkoleń uświadamiających i rozwijających umiejętności ekologiczne pracowników każdego szczebla, zachodzi wysoka korelacja dodatnia wskazująca na istnienie znacznych zależności w badanych obszarach $(\mathrm{rp}=0,68)$. Niewiele mniejsze skorelowanie zachodzi między pytaniami 1.1. i 3.1. $(\mathrm{rp}=0,61)$. W przypadku pytań 1.5. i 3.3. odnoszących się do zielonego zarządzania wydajnością pracowników obserwuje się korelację słabą oznaczającą praktyczny brak związku między zmiennymi.

Należy zatem stwierdzić, że zdaniem członków pokolenia Y najskuteczniejszym sposobem zielonego zarządzania zasobami ludzkimi jest organizacja szkoleń uświadamiających i rozwijających umiejętności ekologiczne pracowników każdego szczebla. Sami również wyrażają największą chęć udziału w takich szkoleniach. Silny związek między nimi potwierdza współczynnik korelacji Pearsona.

\section{Podsumowanie}

Empiryczne badanie przeprowadzone wśród przedstawicieli pokolenia Y zamieszkujących obszar całej Polski umożliwiło realizację celu pracy i dostarczyło interesujących wniosków. W jego wyniku stwierdzono, że wykształcenie członków pokolenia Y warunkuje ich pozytywny stosunek do inicjatyw z zakresu zielonego zarządzania zasobami ludzkimi jedynie w odniesieniu do wprowadzenia przez pracodawcę kodeksu postępowania etycznego uwzględniającego postawy i zachowania proekologiczne oraz organizacji szkoleń uświadamiających i rozwijających umiejętności ekologiczne pracowników każdego szczebla (Hipoteza 1). Można zatem stwierdzić, że są to działania pozytywnie oceniane przez młodszych pracowników, w których aktywny udział powinien zostać im zapewniony. Wyniki badania potwierdziły również, że członkowie 
pokolenia $Y$ tworzą grupę osób zainteresowanych ciągłym rozwojem i zdobywaniem nowej wiedzy, np. podczas szkoleń.

Należy także zauważyć, że przedstawiciele pokolenia Y chcieliby się włączać tylko w te inicjatywy z zakresu zielonego zarządzania zasobami ludzkimi, które sami uznają za najbardziej skuteczne działania w tym zakresie (Hipoteza 2). Ich zdaniem w ramach zielonego rozwoju pracowników pracodawcy powinni organizować szkolenia uświadamiające i rozwijające umiejętności ekologiczne pracowników każdego szczebla. Z kolei w ramach zielonego planowania zasobów ludzkich powinni wdrożyć kodeks postępowania etycznego uwzględniający postawy i zachowania proekologiczne. Co więcej, w odniesieniu do powyższych dwóch inicjatyw badani sami wyrażają chęć aktywnego włączania się w nie. Można zatem stwierdzić, że są oni przedstawicielami pokolenia, które oczekuje od pracodawców podjęcia działań w zakresie zielonego zarządzania zasobami ludzkimi, a także że cechuje ich aktywna postawa wobec niektórych inicjatyw prośrodowiskowych.

Artykuł wnosi wkład do literatury, uzupełniając niewielką liczbę polskich publikacji, w których odniesiono się do inicjatyw z zakresu zielonego zarządzania zasobami ludzkimi z perspektywy członków pokolenia Y (tj. osób urodzonych w latach 1984-1998). Element nowości w artykule stanowi powiązanie oceny skuteczności inicjatyw z zakresu zielonego zarządzania zasobami ludzkimi z chęcią włączenia się w nie wyrażaną przez przedstawicieli pokolenia Y.

Badanie przeprowadzono na niereprezentatywnej próbie badawczej, dlatego prezentacja wyników i rozszerzanie ich na całą populację zostały znacznie ograniczone. W przyszłości należałoby zastanowić się nad przeprowadzeniem badań na większej próbie badawczej obejmującej przedstawicieli pokolenia Y zamieszkujących również poza granicami Polski lub z zastosowaniem formy wywiadu pogłębionego jako uzupełnienia dla badań przeprowadzonych w formie kwestionariusza ankiety.

\section{Bibliografia}

Ackermann, K.F. (2017). Badania nad zielonym zarządzaniem zasobami ludzkimi. Stan według współczesnej wiedzy. Zarzq̨dzanie Zasobami Ludzkimi, 6, 21-39.

Bajdak, A., Janeczek, U., Spyra, Z. (2018). Pokolenie Y wobec narzędzi marketingu mobilnego. Handel Wewnętrzny, 3(374), 27-36.

Baran, M., Kłos, M. (2014). Pokolenie Y - prawdy i mity w kontekście zarządzania pokoleniami. Marketing i Rynek, 5, 923-929.

Bombiak, E., Marciniuk-Kluska A. (2018). Green Human Resource Management as a Tool for the Sustainable Development of Enterprises: Polish Young Company Experience. Sustainability, 10(6), 1-22. 
Bombiak, E. (2019). Zrównoważone zarzq̨dzanie zasobami ludzkim jako wsparcie zrównoważonego rozwoju organizacji. https://core.ac.uk/download/pdf/286574918.pdf, 3.01.2021.

Bugdol, M., Stańczyk, I. (2021). Zielone zarzq̨dzanie ludźmi. Green HRM. Warszawa: Difin.

Bunge, J., Cohen-Rosenthal, E., Ruiz-Quintanilla, A. (1996). Employee Participation in Pollution Reduction: Preliminary Analysis of the Toxics Release Inventory. Journal of Cleaner Production, 4(1), 9-16.

Bangwal, D., Tiwari, P. (2015). Green HRM - A Way to Greening the Environment. IOSR Journal of Business and Management, 17(12), 45-53.

Dubois, C.L.Z., Dubois, D.A. (2012). Strategic HRM as Social Design for Environmental Sustainability in Organization. Human Resource Management, 51(3), 799-826.

Ehnert, I. (2009). Sustainable Human Resource Management: A Conceptual and Exploratory Analysis from a Paradox Perspective. Heidelberg: Springer Science \& Business Media.

Fatyga, B. (1999). Dzicy z naszej ulicy. Antropologia kultury młodzieżowej. Warszawa: Instytut Stosowanych Nauk Społecznych Uniwersytetu Warszawskiego, 126-145.

Geetha, V.U., Sammanasu J.M. (2020). Green HRM - A Conceptual Framework. Journal of Xi'an University of Architecture \& Technology, XII (V), 1204-1212.

Harvey, G., Williams, K., Probert, J. (2013). Greening the Airline Pilot: HRM and the Green Performance of Airlines in the UK. International Journal of Human Resource Management, 24(1), 152-166.

Howard-Grenville, J., Buckle, S., Hoskins, S.B., George, G. (2014). Climate Change and Management. Academy of Management Journal, 57(3), 615-623.

Jabbour, C.J.C., Santos, F.C.S. A. (2008). Relationships between Human Resource Dimensions and Environmental Management in Companies: Proposal of a Model. Journal of Cleaner Production, 16, 51-58.

Jabbour, C.J.C. (2011). How Green Are HRM Practices, Organizational Culture, Learning and Teamwork? A Brazilian Study. Industrial and Commercial Training, 43(2), 98-105. Jackson, S.E., Renwick, D.W.S., Jabbour, C.J.C., Müller-Camen, M. (2011). State-of-the-art and Future Directions for Green Human Resource Management: Introduction to the Special Issue. German Journal of Research in Human Resource Management, 25(2), 99-116.

Jackson, S.E., Schuler, R.S., Jiang, K. (2014). An Aspirational Framework for Strategic Human Resource Management. Academy of Management Annals, 8(1), 1-56.

Jain, N. (2009). What is Green HR and How Can we Implement it Effectively in an Organisation?. http://toostep.com/idea/what-is-green-hr-and-how-can-we-implementiteffectively-in, 3.07.2021.

Jain, N., D'lima Ch. (2018). Green HRM - a Study on the Perception of Generation Y as Prospective Internal Customers. International Journal of Business Excellence, 15(2).

Kmiotek, K. (2012). Pokolenie Y jako wyzwanie dla zarządzania zasobami ludzkimi. Zeszyty Naukowe Politechniki Rzeszowskiej. Zarządzanie i Marketing, 2(285), 51-59. Kopertyńska, M.W., Kmiotek, K. (2014). Oczekiwania pracowników pokolenia Y wobec pracodawców i przełożonych - doświadczenia badawcze. Prace Naukowe Uniwersytetu Ekonomicznego we Wrocławiu, 349, 185-196. 
Kusluvan, S., Kusluvan, Z. (2000). Perceptions and Attitudes of Undergraduate Tourism Students towards Working in the Tourism Industry in Turkey. Tourism Management, 21, 251-269.

Lebowitz, S. (2016). 4 tys. osób w IBM próbowało zrozumieć pracę z młodymi. Oto ich 3 wnioski.https://businessinsider.com.pl/firmy/zarzadzanie/millenialsi-w-pracy-jakie-maja-potrzeby/5cxxl4v, 4.01.2021.

Marcus, A.A., Fremeth, A.R. (2009). Green Management Matters Regardless. Academy of Management Perspective, 23(3), 17-26.

Mazur-Wierzbicka, E. (2015). Kompetencje Pokolenia Y - wybrane aspekty. Studia i Prace Wydziału Nauk Ekonomicznych i Zarzadzania, 39(3), 307-320.

Mishra, R.K., Shulagna, S., Kiranmai, J. (2014). Green HRM: Innovative Approach in Indian Public Enterprises. World Review of Science, Technology and Sust. Development, 11, 26-42.

Muszyńska, W. (2020). Stosunek przedstawicieli Pokolenia Y wobec praktyk budowania marki pracodawcy. Zeszyty Naukowe Polskiego Towarzystwa Ekonomicznego w Zielonej Górze, 7(13), 108-122.

Paillé, P., Chen, Y., Boiral, O., Jin, J. (2014). The Impact of Human Resource Management on Environmental Performance: An Employee-level Study. Journal of Business Ethics, 121, 451-466.

Ren, S., Tang, G., Jackson, S.E. (2018). Green Human Resource Management Research in Emergence: A Review and Future Directions. Asia Pacific Journal of Management, 35, 769-803.

Renwick, D.W.S., Redman, T., Maguire, S. (2013). Green Human Resource Management: A Review and Research Agenda. International Journal of Management Reviews, 15, 1-14.

Różańska-Bińczyk, I. (2020). Gramy w zielone, czyli o praktykach green HR w organizacjach. https://www.karierawfinansach.pl/artykul/wiadomosci/praktyki-green-hr, 2.01.2021.

Różańska-Bińczyk, I., Matejun, M., Matusiak, B.E. (2020). Praktyki green HR we współczesnych przedsiębiorstwach. W: J. Cewińska, A. Krejner-Nowecka, S. Winch (red.), Zarządzanie kapitałem ludzkim - wyzwania, Warszawa: Oficyna Wydawnicza SGH, 77-91.

Sajduk, B. (2015). Nowoczesna dydaktyka akademicka. Kto kogo uczy?. http://dydaktykaakademicka.pl./18, 4.01.2021.

Shah, M. (2019). Green Human Resource Management: Development of a Valid Measurement Scale. Business Strategy and the Environment, 28(5), 771-785.

Solnet, D., Kralj, A., Kandampully, J. (2012). Generation Y Employees: An Examination of Work Attitude Differences. Journal of Applied Management and Entrepreneurship, 3, 36-54.

Striker, M. (2011). Współczesny rynek pracy a oczekiwania pokolenia Y wobec zatrudnienia - wyniki badań empirycznych. Prace Naukowe Uniwersytetu Ekonomicznego we Wrocławiu, 223, 30-38. 
Yong, J.Y., Mohd-Yusoff, Y. (2016), Studying the Influence of Strategic Human Resource Competencies on the Adoption of Green Human Resource Management Practices, Industrial and Commercial Training, 8, 416-422.

Yong, J.Y., Yusliza, M.Y., Fawehinmi, O.O. (2019). Green Human Resource Management. A Systematic Literature Review from 2007 to 2019. Benchmarking. An International Journal, 27(7), 2005-2027.

Zaleśna A., Wyrzykowska B. (2017). Zrównoważone zarządzanie zasobami ludzkimi w praktyce przedsiębiorstw w Polsce. Organizacja i Kierowanie, 1(175), 151-165.

\author{
Abstract \\ Attitude of Generation Y Representatives \\ to Green Human Resources Management
}

\begin{abstract}
Although the concept of green human resource management is widely recognized in the literature, there are few Polish publications that take into account the attitude of the representatives of the $\mathrm{Y}$ generation to initiatives in this field. The aim of the article is to examine how members of the $\mathrm{Y}$ generation perceive initiatives in the field of green human resource management and to indicate whether education determines this attitude. The work is theoretical and empirical. The method of studies of the subject literature and quantitative research were used. According to the respondents, the most effective initiative in the field of green HRM is the organization of training courses to educate and develop environmental skills. On the other hand, education to a limited extent determines the attitude of members of the Y generation to green HRM initiatives. The study was conducted on a non-representative research group, which implies limitations.
\end{abstract}

Keywords: green human resource management, Generation Y, education

\title{
Mgr Weronika Muszyńska
}

Absolwentka studiów magisterskich na kierunku Zarządzanie (specjalność zarządzanie zasobami ludzkimi) w Szkole Głównej Handlowej w Warszawie oraz na kierunku Zarządzanie (specjalność komunikacja w biznesie) na Uniwersytecie Ekonomicznym w Poznaniu. Obecnie doktorantka w Szkole Doktorskiej SGH. Autorka publikacji z zakresu zarządzania zasobami ludzkimi oraz czynna uczestniczka wielu konferencji naukowych. Jej zainteresowania badawcze dotyczą przede wszystkim marki pracodawcy, marki osobistej i sieciowości.

e-mail: wm83763@doktorant.sgh.waw.pl

ORCID: 0000-0001-8388-6342 